\title{
A Personal Biographical Note on the Long March Toward Risk Management in the New Service Economy
}

\author{
by Orio Giarini*
}

My first steps toward risk management and the new service economy were taken inadvertedly in the summer of 1959 in Salzburg, where I heard Daniel Bell delivering his first European lecture on his perception of the post industrial age. At the time, I had just finished university with a thesis on the mobility of factors of production and its relevance to the European integration process.

Since then, the notion of the "post-industrial age" has evolved into a more adequate definition of "the service economy". This occurred in an intellectual context dominated by mainstream economics which, for decades, has concentrated mainly on studying the demand side, whereas the increasingly predominant role of services is clearly related to the reevaluation of the strategic role of the supply side.

In 1959, the notion of a service based economy had not yet surfaced due to the still dominant role of manufacturing in major industries. This was where the action was, and at the end of that same year I began working for a chemical giant. For the next seven years, I was able to learn about a number of key issues:

- The introduction of and battle for new synthetic materials, particularly in the textile sector

- The role of the paint and drug markets

- The organization and function of the world fertilizers market, particularly nitrogen fertilizers. In the latter case, I learned how volatility could hit a market following very minimal fluctuations in supply and demand.

- In other areas I was able to appreciate the importance of a strong research system, guaranteeing the quality and performance of new products.

* Secretary General, The Geneva Association. 
These experiences prepared me to join the Battelle Institute in Geneva in 1965. The Institute employed around 1000 persons for contract research in Geneva and almost as many in Frankfurt. It was part of the Battelle Foundation in the USA, which employed an additional 4000 people and conducted, globally, approximately 10000 research projects per year. Historically, it was the first and largest contract research center in the world. This was a very unique experience, since being a project director involved promoting ideas that could be sold to the European industrial sector as well as world wide. Being able to bring together the knowledge and professionalism of various researchers from the most diverse sectors was essential. It was a difficult and challenging task for several reasons: projects had to be sold to industry in order to receive funding, research had to be well organized and results had to be fully justified, a truly tough entrepreneurial task.

It is through this experience that I uncovered the close and logical relationship between research and insurance. No results from research can be taken for granted at the outset. Uncertainty of outcome is unavoidable. The average project in industry would yield just one positive result in approximately every 10 trials. The probability was much less than one hundred times lower in the pharmaceuticals industry. It was therefore important to learn to select good research projects from a large portfolio. The key was to manage uncertainty in order to produce positive results globally. In addition, as in the insurance market, research projects, especially the very innovative ones, require many years of follow-up before yielding a positive financial return. Therefore, not only did the different projects involve different levels of uncertainty, but there was also the time factor to be taken into account. In the end, research and insurance are the mirror image of each other: both start by defining probabilities, but while industry invests money for research right away, insurance accumulates funds against future, probable and unknown events.

Two other points seemed to me to be fundamental at the time, and they possibly provided greater insight than any formal university education:

The first involves a phenomenon that occurred in the late sixties; namely, the transformation of the industrial production system into a system essentially based on service functions. More specifically, research itself, maintenance, learning how to use tools, repair and prevention for security reasons, recycling and waste management all became an essential part of production. From a supply point of view, most of the manufacturing industry in the modern economy is now predominantly service oriented. This applies to the manufacturing phase and even more to the utilization/distribution phase. All this is clearly the result of the paradoxical effect of modern technology: the more efficient new technologies are, the lower the cost of tools and products and the higher the costs linked to most services.

The second point relates to the fundamental characteristic of modern technology: the notion of vulnerability. Here again we are faced with an awesome paradox: on one hand, modern technology is increasingly efficient and feasibility is better controlled, resulting in lower frequency of accidents and malfunctions. Airplane accidents are more rare today than were accidents with a horse and carriage in the past. Nevertheless, when a major accident occurs, the consequences are more severe (human and social costs are higher) and often economically unbearable. Therefore, vulnerability control becomes a key issue for the management of performance in the modern economic system. Volatility itself, in the financial sector, is part of this larger phenomenon of vulnerability. 
This is why insurance has gradually acquired greater strategic and economic importance. Functioning both as a service and as a mechanism for controlling, reducing, and compensating for various vulnerabilities, it has moved to the center of the economic picture.

This issue can be explored further since the following points are still largely open for economic research:

Since the end of the sixties and beginning of the seventies there has been a change which has modified the role of manufacturing in creating the wealth of nations by introducing new qualitative and quantitative constraints into the elasticity of supply. This explains why economic growth experienced in Europe and other industrialized countries between the end of WW2 and 1973 fell from an average of over $6 \%$ to $3 \%$ per year.

In 1972, a group of top insurance executives pointed to new developments in the relationship between insurance and the economy. This led to the foundation of the Geneva Association in 1973 mainly for the purpose of stimulating economic research with a view to elucidating this issue. A series of studies were carried out in the non-life sector with particular reference to new technologies and their impact on risk management. This was the background to the first research projects in Europe focusing on economic losses in connection with computer systems, vulnerabilities in space operations, superconductivity, catering, and many other industries.

Meanwhile, given that reduction of economic growth to $2-3 \%$ was there to stay, it was at this time rapidly becoming clear that social security systems could not for much longer continue to evolve as they had in previous decades. In addition, fundamental demographic changes and the so-called aging phenomenon (in fact the extension of a person's active life) needed to be taken into account. As a result, the first studies focused on how private insurance and savings could contribute to a new welfare state. Today, these ideas are well understood and widely employed. At the time, however, there were those who deemed such ideas to be inconsistent, convinced as they were that life insurance had no place within social security systems.

Even so, the Geneva Association then began a series of introductory studies on this issue: it should be mentioned that the first study was done for France by two young economists, Dominique Strauss-Kahn and Denis Kessler.

Twenty five years after its foundation, we can safely state that the intuition of its founding fathers concerning the economic issues of the sixties the Geneva Association was established to address has proved to be very sound. This also explains why, for a quarter of a century, the Geneva Association has managed to innovate, stimulate and test new ideas.

The march has been a long one and is far from over. The notion of the service economy must be clarified further and related to more efficient economic policies. The sheer speed of economic change in today's world makes redesign and rethinking of certain traditional operations, models and theories inevitable. Never has the challenge to the profession of economist been greater and more than a little courage is needed to adapt to the new and fundamental economic changes. After all, since Adam Smith, economics has had its roots in the industrial revolution, whereas we are now facing a service economy. 
The staggering development of risk management and insurance worldwide over recent decades, at a rate well beyond that of average world economic growth, is an issue that requires more thorough consideration. Furthermore, there is a crucial cultural factor at stake: the acceptance of uncertainty as the critical connotation of life and development. In the new millennium we need to be increasingly aware that our future lies not in guaranteeing certainty but in better equipping civilization to face uncertainties of every kind, political, social, cultural and psychological. In the words of Karl Popper, it is a key issue for the new open society.

The ideas and experiences mentioned here reflect a very ambitious dream, that of being involved, both intellectually and practically, in activities of great moment. I have, indeed, had the opportunity and privilege to spend twenty five years in fields where issues of great relevance have been researched and confirmed. In many ways the future for society, economics, and risk management is likely to travel the road we in the Geneva Association have mapped out. The onward journey is bound to be fascinating. 